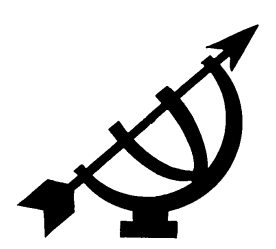

\title{
Christian music in contemporary Africa: a re-examination of its essentials
}

\author{
'Femi Adedeji \\ Department of Music \\ Obafemi Awolowo University \\ Ile-Ife, Osun State \\ NIGERIA \\ E-Mail: olufemiadedeji@yahoo.com
}

\begin{abstract}
Christian music in contemporary Africa: a re-examination of its essentials
\end{abstract}

Christian music all over Africa (be it liturgical church music or gospel), in contemporary times has become so popular and well grown howbeit in divergent dimensions. As a result, there have been questions, debates and confusions both by insiders and outsiders of the Christian faith on what exactly constitutes Christian music. There then arises the need to theorise the fundamentals of Christian music, exhuming the Biblical, musical and socio-cultural basis for its performance practices. This article examines various principles that should guide contemporary Christian musicianship, especially as contained in the Scriptures; arguing that the practice of Christian music cannot be divorced from Bible even when the principles of musical sound organisation and the socio-cultural needs of the society have to be observed. The tension created by the superimposition of the three is also resolved. This article is therefore theoretical and prescriptive in focus and depth as it offers to the African audience the paradigms for understanding the art, gives guidance to the practitioners, and supplies scholarly information to the scholars and observers of Christian studies in general. The article concludes by recommending the indispensability of Biblical standards and skilful originality/artistry in contemporary Christian musicianship. 


\section{Opsomming}

\section{Christelike musiek in kontemporêre Afrika: 'n herevaluering van sy kern}

Christelike musiek regoor Afrika (dus liturgiese kerkmusiek én gospel), het tans uiters gewild geraak ten spyte van die uiteenlopendheid van die dissiplines. As gevolg hiervan het daar vele vrae, debatte en onsekerhede ontstaan by sowel Christene as nie-Christene oor wat nou eintlik as Christelike musiek beskou kan word. Hieruit het die noodsaaklikheid ontstaan om die ware kern van Christelike musiek te teoretiseer, en om die Bybelse, musikale en sosio-kulturele fondament van die hedendaagse beoefening daarvan te ondersoek. Hierdie artikel ondersoek verskeie beginsels, veral Skriftuurlik, wat as riglyne kan dien in die beoordeling van kontemporêre Christelike musiek. Hierdie beginsels stel dat daar 'n direkte verband is tussen Christelike musiek en die Bybel, ten spyte daarvan dat die beginsels van hedendaagse musiek en die sosio-kulturele behoefte van die gemeenskap ook in ag geneem moet word. Die spanning wat ontstaan deur die eise van bogenoemde drie agente, word ook opgelos. Die artikel is daarom teoreties en voorskriftelik in fokus en diepte deur die voorsiening van 'n paradigma aan die Afrikagehoor waardeur hulle kuns kan verstaan, deur leiding aan uitvoerders en musikante te gee en deur wetenskaplike inligting aan navorsers en studente van Christelike studie te verskaf. Die artikel sluit af deur die aanbeveling dat Bybelse standaarde sowel as oorspronklikheid en kunssinnigheid onontbeerlik is in kontemporêre Christelike musiek.

\section{Introduction}

The problem with Christian music today is how to make it Biblically and functionally effective; i.e. making it musically and socially acceptable to people and at the same time without contravening Biblical principles. Various functions and the role of music in African Christianity have been discussed in previous works (Adedeji, 1991; 1999; 2001 and 2002; Ayegboyin \& Ishola, 1997). There are questions and counter questions. Firstly, can Christian music be made to satisfy the interest of people and still remain godly? The Scriptures have stipulated that "friendliness with the world is enmity with God". If people do not like the style and quality of the music, will they want to serve God with it? And of course which one matters most: serving God as He is pleased or serving Him as it pleases us; satisfying Him or satisfying ourselves? But we also need to know that Christian music is multifocused and multifunctional. Its multifocusing and multifunctionality encompass singing to God (whether 
for God as in praise and worship or for ourselves as in praying to God through music); singing to people (whether to them as in evangelising, edifying, exulting, admonishing or for them as in entertainment) and singing to ourselves (whether to comfort, entertain or for self edification). The positive or negative effect that music has on any and all of the three, and especially in terms of Biblicality, multifocusing and multifunctionality then becomes imperative in determining what is right or wrong in Christian music.

From a Nigerian point of view, the need for proper music education in contemporary African Christianity is borne out of the fact that Christian music absorbs diverse features from outside its domain of formation on a daily basis. In another dimension, the proliferation of "avant-garde" churches has ushered in several unconventional styles and performance practices in the Christendom. This development was described by Vidal (2007:2) when he writes:

It is common place to find youths bringing into the context of divine services, especially in non-traditional and orthodox churches, musical genres and vocal styles which captured their attention on satellite TVs and music CDs but which are alien to church music or even to our own culture. Dance music and movie music reminiscent of night club culture are being brought into the Christian religious modes of worship by emerging Christian youths who are expected to be future church leaders.

It is also observed that the quality of Christian music, especially as rendered by many church choirs and independent Christian singing groups, is "poor" and "watery" - both musically and theologically. I have been observing these trends over the years. Also on this observation Vidal (2007:10) writes:

All through the history of the Christian church, church leaders have tried to establish the highest level of aesthetics necessary, for praising and worshipping God in spirit and in truth. Contemporary music which is being used by some churches today would seem to be on the lowest web of aesthetics of music.

Also, since music is an inseparable aspect of religion and an integral part of the liturgy, there is the need for the Christendom to improve on the quality of its music in order to meet contemporary challenges without necessarily getting out of Biblical confines. The first step in this educative venture is a thorough examination of the essentials, i.e. the spiritual and aesthetic principles of Christian music as obtained in the Scriptures. The approach used in this write-up is 
multi-dimensional, combining Biblical, musical and sociological dimensions.

\section{What is Christian music?}

The meaning of the term Christian music has always been assumed in the works of writers and practitioners (Hindley, 1971 \& WilsonDickson, 1992). However, there is the need for a rigorous examination of the term in order to do justice to our topic of discussion. Is Christian music any type of music that is composed by people who call themselves Christians? Or does it include Christian lyrics that are composed and performed by anybody, whether Christian or not? These questions are definitely theological rather than musical. The problem is borne out of the ambiguity in the term. While the word music is general, the word Christian is not, it is rather theological and hence, subjective.

Let us look at the definition from two different angles, firstly, the word Christian may in the broad sense, be interpreted as Christian religion. That being the case, the term Christian music would then be defined as music associated with Christian religion. We can define Christian music as a general term used to describe the agglomeration of music used in Christianity, be it church, para-church, non-church organisations and other settings; church music and gospel music are separate but interrelated categories of this religious form. While church music is limited to church liturgies and activities, gospel music is principally for soul winning (see Adedeji, 2004 for a detailed explanation). This definition makes good sense alongside with the music of other religions. Hence, we talk of Islamic music, Ifa music and so on. Secondly, there is the issue of Biblicality. A practice that is associated with Christianity as a religion, should be based on Biblical parameters. That is the ideal, but it is not always the case. For instance, one religion that has exhibits division mostly is Christianity. There are several denominations and sects with diverse theologies and practices. Yet the holy book of the religion is one - the Bible. Whatever done by those church denominations, whether good or bad, will be associated with the Christian religion. Hence, there is the collective responsibility which the entire Christendom share.

In another dimension, we may also interpret the word Christian in terms of personality. Who then is a Christian? What is the meaning of the word Christian in the light of the Scriptures? We need to reestablish this. In Acts 11:26, the disciples of Christ were first called Christians. John $3: 16,36$ mention faith in Christ as the main 
prerequisite in receiving salvation, an eternal gift meant for Christians. The same faith in Christ is referred to as "receiving Christ" in John 1:12, 13. 1 John 5:1 states that everyone who believes that Jesus is Christ, is a child of God. Paul in Romans 10:9-10 states that confession with lips should complement faith in Christ in establishing a relationship with him.

However, there are other passages in the Scriptures that indicate that "faith in Christ" or "to believe in Christ" or "to receive Christ" both in the heart and in open confession carries other responsibilities. In connection with this view 2 John 1:9 says:

Anyone who goes ahead and does not abide in the doctrine of Christ does not have God: he who abides in the doctrine has both the Father and the Son.

The same idea is expressed in John 8:31:

Jesus then said to the Jews who had believed on him, 'If you continue in my word, you are truly my disciple' ...

Also, Jesus in Matthew 7:21 teaches that doing the will of the Father is required to inherit the kingdom of heaven. Paul in 1 Thessalonians 4:3 explains what the will of God is in this context that He says: "For this is the will of God, your sanctification: That you abstain from unchastity." In John 3:5-7, Jesus teaches that regeneration (a new birth) is a prerequisite to entering heaven. Lastly, Jesus talks about the needed conversion experience as a complementary prerequisite to regeneration (Matt. 18:3). While regeneration refers to a change of spiritual nature, conversion is interpreted as a change in the overall outlook and life style, which is more or less the end result of a true regeneration.

All the above quotations, together with the words of James 2:19 and Paul in Romans 8:14, affirm that believing in Jesus at the superficial level only, does not make one a Christian. To be a Christian is more than mere lip confession. One needs to be a disciple of Christ, one needs to abide in the doctrine of Christ, i.e. to continue in Christ's word, one needs to do the will of the Father. In order to do the will of the Father, one has to abstain from unchastity, one needs to be born again and be converted and one needs to be led by the spirit of God.

Having established the Biblical meaning of the word Christian, we can then go ahead to define Christian music in relation to it. Christian music in this sense will then be music composed by Christians, 
performed by Christians, used by Christians and for Christian multipurpose. We will consider the two dimensions already explained in all our views of Christian music as we highlight the Biblical ideals and describe the contemporary applicability.

\section{The essentials}

What then are the essentials of Christian music? By the term essentials we mean those necessary, indispensable, most important, fundamental or integral characteristics - features of what is called Christian music, i.e. the spiritual and aesthetic principles. In our attempt to do justice to this discussion, we are cognisant of the fact that opinions and views differ greatly. Breimeier (2006b:1) writes in this regards:

Food, colors, fashion sense ... we all have different tastes and preferences for just about everything in life, especially music. It's even reflected in our hymnals and worship styles. Some embrace the liturgical and the old hymns. Some prefer to sing a new song through modern and contemporary pop worship. And many accept a mix of the two through 'blended worship'.

Considering this fact, we must admit that it is virtually impossible to satisfy everybody even as already stated by Breimeier (2006b:1): "One thing you learn fairly quickly as a music critic is that there's simply no pleasing everybody." As deducted from our prolonged definitions above, one of the essentials of Christian music is that the practitioner has to be a Christian. Since this has been thoroughly dealt with, we now move on to other essentials.

\subsection{Theologically-sound text}

According to Marries (1983), the Bible ought to constitute the main source of Christian music texts. One of the distinctive features of music is the text, i.e. the wordings. It is normally expected that the text in Christian music would be Christian. It should also be devoid of "secular" or vulgar slang. More than this, Christian music should have something to communicate in terms of message (Col. 4:6). The text should not be a perambulation; it should be specific and sensible. Some of the themes of contemporary Christian music are praise/worship, invitation, faith, exhortation, Holy Spirit baptism, spiritual warfare, eschatology, prayer and prophecy. These themes and several others are purely theological issues. They are neither social nor political. Gospel music sometimes do address sociopolitical and economic issues, but when it does, it is made to 
condemn bad and criminal behaviours and thus serving as an instrument of discipline and social control.

Apart from all the above, the selected theme of a particular Christian music must be treated rightly and in-depth. This is what it means for the music to be theologically sound. It is not just gambling on spiritual topics. This calls for a good theological knowledge of spiritual issues to be treated in Christian songs. If the composer fails to acquire some theological knowledge of spiritual topics, the endresult is a heresy or wishy-washy text.

It is the responsibility of church apostles, i.e. founders, church administrators, pastors and Christian educators in the church to teach their composers and choristers in general, relevant theological doctrines, thorough sound Bible study and Sunday school programmes. Church musicians who lack the basic understanding in Bible teachings have lost their moral ground. They will only be able to compose shallow and watery music, textually.

\subsection{Biblical purpose}

Based on Ephesians 5:19 and Colossians 3:16, Christian music should as a matter of priority, has Biblical aims and objectives. Other objectives of general music practitioning may be commercial, showmanship or development of musical interest and skill. Biblical aims and objectives include among others, to win souls or to evangelise, to give praise to God, to admonish/exhort, to reprove, to lift spirit up and to comfort one another. This is summed up in the words of Paul - to edify the body of Christ. Christian musicians ought to determine their Biblical motives before embarking on the organisation of music. Purpose is one of the considerable factors in Christian music criticism, i.e. what does the composer aims at? Once the purpose is Biblical then many cloudy aspects in criticism become clear and one could understand the music better.

In another dimension, the Scriptures advise Christians not to do anything whatsoever for the purpose of seeking vain glory, mere show off, or from a competitive spirit (see Gal. 5:26 and Phil. 2:3). There are Christian musicians playing music just to satisfy their musical interests and as part of their career fulfilment. But there is more to Christian musicianship. Two words that need to be explained in relation to this issue are performance and ministration. Performance is generally associated with the practical execution of musical ideas. It connotes playing music for the sake of music. Here the music is the focus. The performance contexts may include among others, 
concerts, socio-political rallies, cultural shows, traditional festivals, social parties and musical competitions. On the contrary, ministration as a theological term refers to discharging divine responsibility or impacting something on others through one's gifts. It is an act of doing God's work and fulfilling his purpose among his people. Music constitutes one of the major areas of Christian ministrations. A Christian artiste playing music in a Christian gathering sees himself as ministering; even in entertainment. This means that the main focus is the primary objective to praise or to preach by using music as a tool. There is a difference between a Christian who performs music and the one that ministers through music.

\title{
3.3 Forms and styles
}

One of the most controversial areas in Christian music scholarship today is the forms and styles that should be used. For instance, each Christian denomination has its own accepted musical forms and styles. While some church denominations accept hymns, some prefer gospel, others choose native airs, and so on. But the Bible is not totally silent on the forms and styles of music that should be used by Christians. Ephesians 5:19 and Colossians 3:16 identify "psalms", "hymns" and "spiritual songs". Martin (1964:47) attempted their definitions and distinctions when he writes:

\begin{abstract}
Psalms may refer to Christian odes patterned on the old Testament Psalter. Hymns would be longer compositions and there is evidence that some actual specimens of these hymns may be found in the New Testament itself. Spiritual songs refer to snatches of spontaneous praise which the inspiring spirit placed on the lips of the enraptured worshipper as 1 Corinthians 14:15 implies.
\end{abstract}

Considering Martin's explanations, we can then conclude that psalms in the contemporary sense are chants composed in the spirit, style and form of Biblical psalms. They can either make direct use of Biblical psalmic texts or adapt similar texts, but they are chanted as in plainchants. Hymns are strophic, metrical and syllabic solemn songs. These are the most important of all the sacred forms today. This is because they retain all the qualities of Christian sacred music. They are highly theological and their normal performance is devoid of side attractions. Spiritual songs may be interpreted as encompassing diverse contemporary Christian forms and styles other than chants (psalms) and hymns. However, such songs should possess all the required spiritual qualities in order to make them truly sacred. Some of these styles include among others 
"spirituals", a-cappella, anthems, canticles, carols, mass, and gospel. The area of greatest controversy is the use of secular beat styles like rock, jazz, blues, and other "popular" and "pop" styles. Many scholars, writers and Christians denounce the use of these styles completely in the church. Their arguments are, firstly, that those styles are primarily associated with club houses, various satanic practices and social vices. Secondly, the instrumentation, rhythms, and side attractions such as dances occupy the mind of the singers and listeners instead of the message of the music. Besides, they arouse bad behaviour in youths. Vidal (2007:2) in support of these arguments writes:

Rock music, like rhythm and blues, is a jazz influenced music. Although rock music started as a teenage rebellion, it later degenerated into a culture characterized by drugs, sex and hallucination among the youths.

These arguments are supported by the Biblical injunction to Christians not to be unequally yoked with the unbelievers in 2 Corinthians 6:14-18.

But there is also the issue of using music at Christian social services. Some people believe those styles are indispensable here, except Christians will not socialise at all. From my understanding of the Scriptures, the entertainment function of music was legitimate in the New Testament era especially as implied in James 5:13 and Luke 15:23-25:

Is any among you afflicted? Let him pray. Is any merry? Let him sing psalms.

And bring hither the fatted calf, and kill it; and let us eat, and be merry: For this my son was dead, and is alive again; he was lost, and is found. And they began to be merry. Now his elder son was in the field: and as he came and drew nigh to the house, he heard music and dancing.

The style of music that would enhance dancing as instructed above will be instrumental and danceable. All such songs composed will definitely fall into duple, triple, quadruple (simple or compound) beats and will be expressed in any of the traditional, "popular" or "pop" music beats. Since we have not heard of a heavenly beatstyle, we have no alternative than to use them in so far as they enhance the purpose. 
Another reason to reconsider the use of secular styles is the argument of converted secular artistes that use their former styles in singing gospel songs for the purpose of ministering to their counterparts who are yet to be converted. They claim the style they are using constitutes their own weapon of evangelising people. For instance, evangelist Sonny Okosuns in Nigeria, an internationally acclaimed reggae artiste that now turned gospel singer, is using his gift and style to minister several secular artistes and reggae addicts. But then there is still need for a caution here. Despite the aforementioned, it is unethical for Christians to bring in mannerisms, nuances and idiosyncrasies of secular artistes into their ministrations, which are supposed to be spiritual. For instance, it is abominable for a Christian singer whether in or outside the church, to imbibe Bob Marley's antics and lifestyles in their music ministrations.

It is important at this juncture to make some clarifications. It is not compulsory that a particular church should make use of all the three broad categories of forms in its liturgy. At the same time, a church denomination, which favours the use of one, has no moral justification in condemning another church denomination, which prefers another form, once it is one of the Biblical forms. To my mind, on the contrary, a particular church denomination may make use of the three categories as dictated by contexts. Church sacraments such as the Lord's Supper and baptism require the use of very solemn forms. Psalms and hymns would be more appropriates. Lyrics airs would be suitable for revival meetings while gospel airs would be ideal for other Christian non-liturgical functions.

\subsection{Good sound organisation}

Organisation of music concerns the physical dimension of music. Christian music in order to be truly Christian and really musical needs to be spiritual and artistic. The artistry and creativeness of music in the service of God is encouraged in the Scriptures: "For God is the King of all the earth: sing ye praises with understanding" (Ps. 47:7). This idea is forcefully expressed in the words of Olukoju (1987:125):

According to the Papal instructions as cited by Reverend Father R.P. Peters, 'religious music is neither African nor European, it is universal or it does not exist, and for it to be universal, it must be artistic and holy'. 
Most of what we have discussed so far, concern the spiritual, which is the metaphysical dimension of music. It is not enough to have spiritual requirements in music. There is the need for creative organisation of the musical elements. The fact that a composer or performer is a highly spiritual person does not guarantee good music. For music to be good aesthetically, it has to be original, creative and well organised. There are rules that guide the organisation of music according to various cultures - Western, African, Judaeo-Christian, et cetera. For example, African languages are tonal and music in African concept is text-bound. These rules have to be observed in order to achieve what is musically good and culturally relevant. Christian music practitioners should familiar themselves with those rules and make use of them, since they could not be accommodated in this article.

Important elements of music include melody, harmony and rhythm. Melodies in Christian music should be beautiful, attractive and well singable. They should also be well fitted to the texts. The composer needs to consider these while composing a melody. If a melody does not posses those characteristics, the psychological output of the music cannot be good, however good the performers may be. The type of harmony to be used in a composition must be the one that enhance the melodic movement and contour. The choice of harmonic tones depends on the musical scale used and the style of music being composed. The harmony must also be effective and make the music richer. Rhythm should be properly organised. The dynamic use of rhythm could make a musical composition very interesting. This is because rhythm is an essential element in music. The natural rhythm of the language, style and phraseology should all be considered while organising rhythm in music.

In order to achieve good sound organisation, there is the need that the practitioners acquire skill in addition to musical talent. Many people are interested in one aspect of music or the other without talent or skill. When people have both, it makes a difference. Church denominations and Christian organisations should always commit the organisation of music in their respective places into the hands of skillful musicians. The significance of skillfulness is demonstrated in the Scriptures (1 Chron. 15:22) where Chenaniah is made the voice/singing instructor because of his skill: "Chenaniah, leader of the Levites in Music, should direct the music for he understood it." 


\subsection{Packaging}

The term packaging is associated with production; applicable to its final stage. The term is used here to indicate the way musical works are made ready for delivery, i.e. the finishing. It is associated more with performance. It is not enough that a particular music is well composed and arranged. There is the need to package it well (see Breimeier, 2006a). How? Life performances should make use of good instruments and voices. They should also be well coordinated so that the music could be transmitted to the audience in good quality, in terms of technicality. In recorded works, latest technology, good engineering works, editing and balanced mixing should be ensured in order to have good packaging. Rough packaging does not encourage embrace of the audience, however good the music may be in terms of originality and creativity. To ensure good packaging, church denominations and Christian organisations should procure current and sophisticated musical instruments and equipments. If standard is what we aim at, then we must spend money. Whatever amount spent in this regard is not a waste.

\subsection{Stagecraft and performance ethics}

One big problem in Christian music practitioning stems from the facts that on one hand music has its aesthetic rules which should be obeyed in order to have beautiful music and on the other, there are stipulated laws in the Scriptures which should guide Christians in the way and manner they do things (including works of arts). Music has to be good and at the same time, God's laws ought not be violated. How then do we strike the balance? The problem becomes more serious when one considers the truism that we should adjust ourselves to the Bible rather than adjusting the Bible to ourselves. Speaking about Christian music of the Western medieval period, Robertson (1950:13) writes:

There was, indeed, a marked antithesis between the secular music of the time and the kind of music felt to be suitable for Christian worship: restraint, tranquility, nobility and solemnities were not qualities to be found in theatrical entertainments or at private parties, nor could such music be said to express states of the soul!

Implied in the words of Robertson is the fact that restraint, tranquility, nobility and solemnities should characterise Christian music. These were all to be found in the Early and Medieval Church music. Let us now examine issues in stagecraft and performance ethics one by one. While stagecraft has to do with skill or mastery of stage 
performance (including stage mannerism), performance ethics refers to the ways and manners of music performance generally.

A Christian artiste needs to expose him-/herself to stage performances and also study closely live performances of professional and experienced Christian artistes However, he/she should avoid vulgar slang and jargons associated with the gay community or hooligans. In relation to this, the Bible states in Colossians 4:6:

Let your speech always be gracious, seasoned with salt, so that you may know how you ought to answer everyone.

Secondly, in line with Biblical injunction in 1 Corinthians 14:40, Christian music should be presented decently and orderly. Christian musician should not imitate unchristian acts and stylistic features associated with cults and satanists. Direct imitation of secular melodies on instruments should also be avoided. These practices do not edify. They rather corrupt our minds and pollute our music. For instance, there is no sin in dancing. The Bible rather encourages it. However, why should Christian music feature dances in some secular styles which are sexually provocative, erotic and caution less?

In 1 Corinthians 10:23, Paul discourages us from indulging in things that are neither spiritually profitable nor expedient. He says: "All things are lawful, but not all things are helpful. All things are lawful, but not all things build one up." He goes further to advice us in 1 Corinthians 14:40: "but all things should be done decently and in order". All forms of carnality in Christian music performance are not Biblical. A Christian artiste should therefore avoid pride, unnecessary boasting and display of over-confidence.

Another point of consideration is that it is unethical for Christian musicians to sing in the language not well understood by the audience. Rather the language best understood should be used. In this way, the message will be more appreciated.

Costume and side attractions should be moderate as the Scriptures instruct. Flamboyant, extravagant and seductive dressings are not Biblical. The side attraction that will divert the attention of the audience from the message should be discouraged. Whatever we believe, the Bible has not minced words concerning our mode of dressing as Christians. Whether a priest, dramatist, musician or fashion designer; whatever the professional background, once you are a Christian, the Bible has indicated the standard Christians 
should meet. Today, we have philosophised our faith, we have reconceptualised it and we have modernised it. Of course, who cares? Once we are satisfied and happy, God should be pleased, we assumed. There may not be an end to the innovations and inventions our generation is bringing into the Christian faith today. Of course, Solomon observes the existence of God's standard and man's standards in Ecclesiastes 7:29, when he says: "Lo, this only have I found, that God hath made man upright; but they have sought out many inventions."

Our creativity, philosophies, inventions and innovations will never change the Biblical standard. Even when we build attractive and convincing arguments around our inventions, the Bible remains forever the same (Ps. 119:89). See for reference the following passages 1 Peter 3:3-5; 1 Timothy 2:9, 10; Isaiah 3:16-26 and 1 Corinthians $7: 31$.

Moreover, the Bible admonishes females to cover their head while ministering, especially when they maintain long hair (1 Cor. 11:5-6). And to both sexes, the Bible commands not to put on what belongs to the opposite sex (Deut. 22:5). For instance, a male Christian artiste that plaits or weaves his hair like female and put ear rings on while ministering, might not see anything wrong with it musically and socially, more especially that he is a talented singer and a youth, but much may be wrong with it spiritually.

\subsection{Living by the message of the music}

The last essential of Christian music to be explored is living by the message of the music. This has been extensively discussed by Adegboye (2003). It is expected that Christian artistes should practice what they sing (see Jam. $1: 25 ; 2: 12$ ). The more they do this, the more people believe them and take them serious. One of the banes of Christianity today is that the adherents do not practice what they teach and this is why the gospel they preach seems powerless and feeble to change the morally decadent societies. One can ask a popular question, should Christian artistes or church choirs make use of unbelievers, drunks and public immorals as guest instrumentalists or singers on the stage/in the church? As may be deducted from several Scriptures referred to in this article, the answer is No! Christians should restrain from habits that remove God's anointing on their music and destroying their Christian testimonies. 


\section{Conclusion}

In conclusion, it is pertinent to recommend that Christian musicians and artistes, whether in Africa or Asia, Europe or America, go by Biblical standards. In order to enhance this, it is recommended that Christian musicians have sound knowledge of the Scriptures, especially in the area of music. However, it should be noted that theological education does not guarantee uniformity of practice. This is because different Christian denominations have different theologies, as may be determined by presuppositions, cultural backgrounds and peculiar contextual situations. All the same, general prerequisites as asserted in this article may be regarded as basics on which our contemporary Christian musical practices could be based.

In order for the church by its music to be relevant to the contemporary world without forsaking Biblical principles, effectiveness of functionality should be the purpose. The church should not give what the world wants but what it needs. If Christian music should save, heal, deliver, admonish, edify, praise God and profitably entertain, it must be rearmed with "spiritual power" to perform the tasks, which can only be appropriated in prayer. The church needs to maintain its testimonies if it must truly change the world through its music. Besides, contextualisation as a methodology must be applied to Biblical principles guiding Christian music as an art. This means that the Scriptures and their interpretations must not be bent to suit our interests but the application may differ from one context to the other, in terms of purpose, multifoci, functionality and societal needs. African Christians should take caution in their adoption of American Christian values which continue to enjoy and spread throughout the globe, an unrestricted and unguided freedom. This may be catastrophic!

\section{List of references}

ADEDEJI, S.O. 1991. Music education in African instituted churches. Book 1. Nairobi: Organisation of African Instituted Churches.

ADEDEJI, S.O. 1999. The role of music in God's work. Ile-Ife: Bolakay Press.

ADEDEJI, S.O. 2001. Revolutionary trends in Nigerian contemporary gospel music. Humanities review journal, 1(2):46-53.

ADEDEJI, S.O. 2002. Composing music for Nigerian contemporary Christian liturgies. Nigerian music review, No. 3:90-99.

ADEDEJI, S.O. 2004. Nigerian gospel music: a study of its styles. Ibadan: University of Ibadan. (Unpublished Ph.D. thesis.)

ADEGBOYE, D. 2003. What every Christian musician should know, be, do and flee Offa: Gospel Unlimited. 
AYEGBOYIN, DEJI \& ISHOLA, S.A. 1997. African indigenous churches: an historical perspective. Lagos: Greater Heights.

BREIMEIER, RUSS. 2006a. Inside the world, outside the box: Christian music today. http://www.Christianitytoday.com Date of access: 20 Nov. 2006.

BREIMEIER, RUSS. 2006b. Music we all can tolerate? Christian music today. http://www.Christianitytoday.com Date of access: 15 April 2007.

HINDLEY, GEOFFERY. 1971. The Larousse encyclopedia of music. London: Hamlyn.

HOLY BIBLE. 1971. Revised Standard Version. The British \& Foreign Bible Society.

MARRIES, ANDREW. 1983. Using the Bible in music. Swindon: Bible Society.

MARTIN, R.P. 1964. Worship in the Early Church. Grand Rapids: Eerdmans.

MILLER, E.F. 1993. Building an effective church music ministry. Ibadan: Baptist Press.

OLUKOJU, E.O. 1987. Music in religious worship. Ibadan journal of religious studies, 19(2):118-133.

ROBERTSON, ALEC. 1950. Sacred music. London: Max Parrish.

VIDAL, A.O. 2007. Rock music at divine services: good or bad? (Unpublished paper.)

WILSON-DICKSON, ANDREW. 1992. A brief history of Christian music. Oxford: Lion Publishing.

\section{Key concepts:}

Biblical music

Christian music

church music

music and theology

Kernbegrippe:

Bybelse musiek

Christelike musiek

kerkmusiek

musiek en teologie 